\title{
UJI KUALITAS KUE SATU BERBAHAN TEPUNG KARA KRATOK (PHASEOLUS LUNATUS L)
}

\author{
Komang Eva Suryastini, Ni Made Suriani, Damiati \\ Program Studi Pendidikan Kesejahteraan Keluarga, Fakultas Teknik dan Kejuruan \\ Universitas Pendidikan Ganesha \\ Singaraja, Indonesia
}

e-mail : evasuryastini01@gmail.com, made.suriani@undiksha.ac.id,damiati@undiksha.ac.id

\begin{abstract}
Abstrak
Penelitian eksperimen ini bertujuan untuk mengetahui kualitas kue satu berbahan tepung kara kratok (Phaseolus lunatus $L$ ) yang dilihat dari aspek (1) aroma, (2) rasa, dan (3) tekstur. Panelis dalam penelitian ini menggunakan panelis terlatih yang terdiri dari 20 orang panelis. Metode pengumpulan data yang digunakan dalam penelitian ini yaitu metode observasi dengan menggunakan instrumen berupa lembar uji organoleptik dengan 3 tingkatan yaitu baik, cukup, kurang. Data dianalisis dengan menggunakan teknik analisis data deskriptif kuantitatif. Hasil penelitian ini menunjukkan (1) Kualitas kue satu berbahan tepung kara kratok dilihat dari aspek aroma berada dalam kategori baik $(3,00)$, sesuai dengan tolok ukur yaitu khas kacang kara kratok. (2) Kualitas kue satu berbahan tepung kara kratok dilihat dari aspek rasa berada dalam kategori baik $(2,85)$, sesuai dengan tolok ukur yaitu manis. (3) Kualitas kue satu berbahan tepung kara kratok dilihat dari aspek tekstur berada dalam kategori baik $(2,85)$, sesuai dengan tolok ukur yaitu rapuh
\end{abstract}

Kata kunci: Tepung Kara Kratok, Kue Satu, Aroma, Rasa, Tekstur

\begin{abstract}
This experimental study aims to determine the quality of kue satu made from kara kratok flour (Phaseolus lunatus L) which is seen from the aspects of (1) aroma, (2) taste, and (3) texture. Panelists in this study used trained panelists consisting of 20 panelists. The data collection method used in this study is the observation method using an instrument in the form of an organoleptic test sheet with 3 levels: good, enough, less. Data were analyzed using quantitative descriptive data analysis techniques. The results of this study indicate (1) The quality of kue satu made from kara kratok flour viewed from the aspect of aroma is in the good category (3.00), which is typical of kara kratok beans. (2) The quality of kue satu made from kara kratok flour viewed from the aspect of taste is in the good category (2.85), which is sweet. (3) The quality of kue satu made from kara kratok flour viewed from the aspect of texture is in the good category (2.85), which is fragile.
\end{abstract}

Keywords: Kara Kratok Flour, Kue Satu, Aroma, Taste, Texture

\section{PENDAHULUAN}

Negara Indonesia merupakan salah satu negara yang memiliki potensi sumber daya alam yang melimpah. Negara yang terletak pada daerah tropis yang memiliki curah hujan cukup tinggi yang membuat tumbuhan mampu tumbuh subur di tanah Indonesia. Contohnya seperti sumber daya alam pada bidang pertanian.
Bali merupakan salah satu provinsi yang ada di Indonesia yang memiliki sumber daya alam yang melimpah dan berpotensi untuk dikembangkan. Sumber daya alam tersebut diantaranya seperti sayur-sayuran, buah-buahan, kacangkacangan atau polong-polongan, dan sumber bahan pangan lainnya.

Kacang-kacangan merupakan sumber protein nabati yang penting dalam upaya perbaikan gizi. Hal ini disebabkan 
oleh kandungan protein yang cukup tinggi, pengadaannya mudah dan relatif murah harganya dibandingkan dengan sumber protein hewani (Utomo dan Antarlina, 1998).

Jenis kacang-kacangan yang tidak asing lagi di masyarakat adalah korokoroan yang mengandung protein cukup tinggi. Beberapa jenis koro-koroan yang terkenal di masyarakat antara lain koro komak, pedang, dan kratok dengan kandungan protein yang berturut-turut $18,85 \%, 21,87 \%, \quad 14,10 \%$ (Subagio, 2003).

Koro kratok atau kara kratok (Phaseolus lunatus L) atau disebut juga dengan roay oleh masyarakat Jawa Barat adalah tanaman sayuran merambat yang biasa dikonsumsi (Sanjaya, 2005). Kara kratok yang termasuk anggota dari golongan kacang-kacangan (Leguminosae) adalah tanaman tahunan, tetapi dibudidayakan sebagai tanaman setahun (annual).

Kara kratok (Phaseolus lunatus $L$ ) berasal dari Neutropik dengan dua daerah domestika yaitu Amerika Tengah (meksiko, Guatemala) untuk yang berbiji kecil dan Amerika Selatan (terutama Peru) untuk yang berbiji besar. Pelaut-pelaut Spanyol membawanya melintasi Pasifik ke Filipina, kemudian menyebar ke wilayah Asia, terutama Jawa, Burma, dan Mauritius.

Di akhir abad 19, tanaman ini mulai ditanam di Minahasa, dan di waktuwaktu berikutnya juga di Jawa bagian timur, sebagai tanaman penutup tanah untuk mengatasi aneka gulma kebun yang merugikan. Meskipun dinilai kurang mampu menekan pertumbuhan gulma, kara kratok dipandang cukup berguna karena membentuk penutup tanah dan menghasilkan banyak humus yang menyuburkan tanah.

Polongnya yang muda direbus dan dimakan sebagai sayuran. Bijinya yang tua, khususnya kultivar kacang jawa, mengandung asam sianida, sehingga harus diolah terlebih dulu sebelum dapat dimakan dengan aman. Pengolahan itu di antaranya dengan merendamnya di air, merebusnya, atau memfermentasikannya sehingga racunnya hilang.
Kara Kratok (Phaseolus lunatus $L$ ) merupakan salah satu jenis koro-koroan yang tumbuh subur di Kabupaten Bangli. Berdasarkan hasil wawancara pada tanggal 29 April 2019 dengan Kepala BPP Kintamani Barat, Bapak I Made Suweca, $\mathrm{SP}$, mengatakan bahwa komoditas kara kratok tumbuh subur di beberapa desa yang ada di Kabupaten Bangli diantaranya di Desa Sukawana, Desa Langgahan, Desa Catur, Desa Siyakin, Desa Satra, Desa Ulian. Tanaman kara kratok merupakan tanaman tahunan. Syarat tumbuhnya yang dapat dikatakan mudah karena dapat tumbuh di pagar-pagar. Penanaman kara kratok biasanya dilakukan pada bulan Juni, Juli, dan Agustus. Setelah tiga bulan kemudian, tanaman kara kratok sudah dapat berbuah.

Berdasarkan hasil observasi di Pasar Anyar Buleleng, kara kratok dijual dalam bentuk masih segar dan juga ada yang sudah kering. Harga kara kratok dalam bentuk masih segar atau basah dijual dengan harga yang lebih mahal dibandingkan dengan kara kratok yang sudah kering. Hal tersebut disebabkan karena rasa kara kratok yang masih segar atau basah dinilai lebih enak sehingga kara kratok lebih banyak diminati oleh konsumen dan dijual dengan harga relatif mahal dibandingkan dengan kara kratok yang sudah kering. Berdasarkan hasil wawancara dengan Kepala BPP Kintamani Barat, Bapak I Made Suweca, SP mengatakan bahwa pengeringan kara kratok bertujuan agar kara kratok dapat bertahan dengan waktu yang lama, pengeringan tersebut merupakan salah satu strategi petani kara kratok ketika musim panen dan hasil kara kratok melimpah.

Kara kratok atau koro kratok memiliki kelemahan yaitu di dalam kara kratok mengandung senyawa anti nutrisi yang disebut dengan senyawa asam sianida ( $\mathrm{HCN})$. Asam sianida ( $\mathrm{HCN})$ merupakan senyawa racun yang dapat berdampak buruk terhadap kesehatan tubuh apabila mengkonsumsinya secara berlebihan. Kandungan senyawa anti nutrisi dan racun koro kratok $(\mathrm{HCN})$ sangat tinggi yaitu $111,8 \mathrm{mg} / 100 \mathrm{~g}$. 
Salah satu upaya untuk mengurangi asam sianida ( $\mathrm{HCN})$ yang terkandung di dalam kara kratok yaitu mengolah kara kratok menjadi tepung. Tepung merupakan partikel padat yang berbentuk butiran halus atau sangat halus tergantung pada proses penggilingannya (https://id.wikipedia.org/wiki/Tepung)

diakses pada tanggal 19 April 2019. Pada proses penepungan, kara kratok melalui tahap perendaman dan perebusan. Pada tahap perendaman, harus benar-benar diperhatikan karena semakin lama prendaman dilakukan, maka semakin banyak asam sianida yang dapat dihilangkan (Sri, dkk., 2008).

Dewasa ini, pemanfaatan tepung kara kratok masih belum optimal. Berdasarkan hasil wawancara pada tanggal 25 April 2019 dengan Kasi Produksi Tanaman Pangan Kabupaten Bangli mengatakan bahwa hasil panen kara kratok dijual langsung oleh petani dalam bentuk masih segar dan kering. Biasanya kara kratok diolah oleh masyarakat untuk dijadikan lauk pauk pendamping makanan pokok. Belum ada produksi kara kratok dalam bentuk tepung-tepungan.

Berdasarkan analisis data dari penelitian yang dilakukan oleh $\mathrm{Ni}$ Putu Erni Widia Astuti dengan judul penelitian "Uji Kualitas Tepung Kara Kratok" dengan hasil penelitian bahwa proses pembuatan tepung kara kratok diantaranya yaitu penyortiran, perendaman, pengupasan kulit ari, perebusan, pengeringan, penggilingan, pengayakan, dan pengemasan. Kandungan zat gizi tepung kara kratok meliputi karbohidrat 53,09\%, protein $29,94 \%$, lemak $1,88 \%$, abu 3,94\%, air $11,12 \%$, dan pati $34,66 \%$. Kualitas tepung kara kratok dilihat dari aspek warna berada pada kategori baik yaitu putih bersih, tidak kotor, dan tidak ada bintik-bintik warna. Dilihat dari aspek aroma berada pada kategori baik yaitu tidak apek dan beraroma khas kara kratok. Dilihat dari aspek tekstur, memiliki tekstur halus dan tidak menggumpal.

Berdasarkan jumlah gizi yang terkandung di dalam tepung kara kratok dan tepung kacang hijau, zat gizi protein pada tepung kara kratok lebih tinggi
Melihat hasil penelitian di atas, diketahui bahwa kandungan gizi tepung kara kratok cukup tinggi. Terutama pada zat gizi karbohidrat. Karbohidrat merupakan sumber zat gizi sumber energi bagi tubuh sehingga tubuh dapat beraktivitas dengan baik.

Berdasarkan hasil uji laboratorium di UPT. Laboratorium Analitik, Universitas Udayana, kandungan asam sianida $(\mathrm{HCN})$ tepung kara kratok yang dibuat dengan menggunakan tahapan penyortiran, perendaman, pengupasan kulit ari, perebusan, pengeringan, penggilingan, pengayakan yaitu $0,130 \mathrm{mg} / \mathrm{g}$ atau sama dengan $13 \mathrm{mg} / 100 \mathrm{~g}$. Dengan demikian, sudah terbukti bahwa proses penepungan dapat mengurangi senyawa asam sianida yang terkandung di dalam kara kratok. Tepung kara kratok masih aman untuk dikonsumsi.

Dalam upaya mengoptimalkan pemanfaatan hasil produk setengah jadi yaitu tepung kara kratok, peneliti ingin berinovasi memanfaatkan tepung kara kratok untuk dijadikan suatu hidangan berupa kue kering yaitu kue satu. Kue satu merupakan salah satu kue tradisional khas Betawi. Bahan-bahan lainnya diantaranya yaitu gula halus, air hangat, dan garam, Sebelum dikeringkan, adonan kue satu dicetak terlebih dahulu menggunakan cetakan kue satu.

Kue satu rasanya manis dengan bahan dasar kacang hijau sering dijadikan sebagai oleh-oleh khas dari Tanah Pasundan. Dalam proses pencetakannya, kue satu dicetak satu per satu. Berdasarkan resep aslinya, pembuatan kue ini masih memegang teguh cara pembuatan tradisional. Misalnya saja, menggunakan paparan sinar matahari dalam proses pengeringan kue (Fachni, 2016). (https://budaya-indonesia.org/KueSatu-1/) diakses tanggal 18 April 2019.

Adapun kandungan gizi yang terdapat dalam tepung kacang hijau antara lain karbohidrat $72,86 \%$, protein $19,09 \%$, lemak $0,09 \%$, abu 0,1\%, dan air 5,07 \% (Susanto dan Saneto, 1994).

dibandingkan dengan tepung kacang hijau. Protein adalah zat makanan berupa asam-asam amino yang berfungsi sebagai pembangun dan pengatur bagi tubuh. 
Protein mengandung unsur karbon, hidrogen, dan nitrogen yang tidak dimiliki oleh lemak atau karbohidrat. Molekul protein juga mengandung posfor, belerang serta beberapa protein memiliki unsur logam seperti zat besi dan tembaga (Budianto, 2009).

Inovasi yang ingin peneliti lakukan adalah memanfaatkan tepung kara kratok menjadi kue satu dengan menggunakan teknik pengeringan dijemur. Kacang hijau dan kara kratok sama-sama berasal dari kacang-kacangan. Karakteristik tekstur kue satu yang rapuh sehingga tepung kara kratok cocok untuk diolah menjadi kue satu. Kue satu berbahan tepung kara kratok akan menggunakan teknik pengeringan dengan cara dijemur di bawah sinar matahari langsung. Kemudian peneliti akan menguji kualitas kue satu berbahan tepung kara kratok dari aspek aroma, rasa, dan tekstur.

Berdasarkan penelitian yang dilakukan oleh Kusnul Khotimah (2014), yang meneliti tentang "Uji Kualitas Kue Kering (Kue Satu) Kacang Koro Pedang (Canavalia Ensiformis (L) DC) dengan Teknik Pengolahan Dijemur dan Dioven)". Hasil penelitian menunjukkan bahwa 1) kualitas kue kering (kue satu) kacang koro pedang dengan teknik pengolahan dijemur dilihat dari aspek aroma berada

\section{METODE}

Penelitian yang dilaksanakan oleh penulis ini dilaksanakan di Laboratorium Produksi Program Studi Pendidikan Kesejahteraan Keluarga. Metode yang digunakan dalam penelitian ini adalah metode eksperimen dan hasilnya akan diuji melalui uji kualitas (organoleptik) dengan menggunakan 20 orang panelis terlatih. Pengumpulan data pada penelitian ini dilaksanakan di Program Studi Pendidikan Kesejahteraan Keluarga, Undiksha Singaraja, SMK Negeri 2 Singaraja, dan SMK Pariwisata Triatma Jaya Singaraja pada tanggal 12 Juni 2019 sampai 17 Juni 2019. dalam kategori baik $(2,85)$ yaitu khas kacang koro pedang, rasa dalam kategori baik $(2,90)$ yaitu manis, dan tekstur berada dalam kategori baik $(2,85)$ yaitu rapuh. 2) kualitas kue kering (kue satu) kacang koro pedang dengan teknik pengolahan dioven dilihat dari aspek aroma berada dalam kategori baik $(2,66)$ yaitu khas kacang koro pedang, rasa dalam kategori baik $(2,71)$ yaitu manis, dan tekstur berada dalam kategori baik $(2,33)$ yaitu agak keras. Berdasarkan penelitian uji kualitas kue kering (kue satu) kacang koro pedang (Canafalia Ensiformis (L) $D C$ ) dengan teknik pengolahan dijemur dan dioven secara keseluruhan berada dalam kategori baik, yang membedakan hanya terdapat pada aspek tekstur yaitu agak keras.

Untuk mengetahui kualitas kue satu dapat menggunakan alat indera yang dimiliki oleh manusia diantaranya yaitu indera penglihatan, indera penciuman, indera peraba, dan indera perasa. Pada penelitian ini, kualitas kue satu yang akan dikaji yaitu dari segi aroma, rasa, dan tekstur.

Berdasarkan pemaparan di atas, peneliti akan mengadakan penelitian dengan judul "Uji Kualitas Kue Satu Berbahan Tepung Kara Kratok (Phaseolus lunatus $L)$ ".

$\begin{array}{lll}\text { Jenis } & \begin{array}{l}\text { penelitian ini adalah } \\ \text { penelitian }\end{array}\end{array}$ menggunakan desain penelitian The One Shot Case Study yaitu perlakuan yang diberikan terhadap suatu kelompok selanjutnya dilakukan pengambilan data. Suatu kelompok yang diberikan perlakuan (treatment) dalam peneltian ini adalah tepung kara kratok yang diolah menjadi kue satu. Kemudian diobservasi hasilnya berupa hasil uji kualitas kue satu berbahan tepung kara kratok.

Penelitian ini menggunakan resep kue satu kacang hijau sebagai resep kontrol. Dari resep tersebut, peneliti bereksperimen mengganti bahan utama yaitu kacang hijau menjadi tepung kara 
kratok dengan menggunakan formulasi bahan $100 \%$ tepung kara kratok. Bahan tambahan yang digunakan adalah gula halus, garam, dan air hangat. Pada pembuatan kue satu kara kratok tidak pengeringan yang digunakan adalah dengan cara dijemur di bawah sinar matahari langsung. Tujuannya adalah untuk mengurangi kadar air yang terdapat dalam adonan kue satu. Hasilnya

\section{HASIL PENELITIAN DAN PEMBAHASAN}

\section{Proses Pembuatan Kue Satu Kara Kratok}

Kue satu kara kratok yang diuji kualitasnya dari aspek aroma, rasa, dan tekstur mengacu pada resep standar kue satu kacang hijau (Damiati, 2011). Kue satu kara kratok pada penelitian ini menggunakan $100 \%$ bahan utama yaitu mengganti tepung kacang hijau dengan tepung kara kratok. Beberapa tahapan dalam proses pembuatan kue satu kara kratok adalah tahap persiapan, tahap pengolahan, dan tahap penyajian yang pemaparannya adalah sebagai berikut.

\section{Tahap Persiapan Bahan dan Alat}

Pada tahap persiapan meliputi persiapan bahan dan alat. Bahan-bahan yang digunakan dalam pembuatan kue satu kara kratok adalah bahan-bahan yang bersih dan terbebas dari kotorankotoran lainnya. Bahan-bahan yang diperlukan dalam proses pembuatan kue satu kara kratok antara lain tepung kara kratok, gula halus, garam, dan air hangat.

Kue satu kara kratok terbuat dari tepung kara kratok sebagai bahan utamanya. Resep yang digunakan mengacu pada resep kue satu kacang hijau (Damiati, 2011). Namun, bahan tambahan yang digunakan pada kue satu kara kratok antara lain gula halus, garam, dan air hangat. Peneliti menghilangkan bahan tambahan vanili dengan tujuan agar dapat mempertahankan aroma khas kara kratok. Berikut merupakan bahan- menggunakan bahan vanili dengan tujuan untuk mempertahankan aroma khas kara kratok. Adonan kue satu berbahan tepung kara kratok ini akan dicetak menggunakan cetakan kue satu. Teknik akan diuji kualitasnya yang ditinjau dari aspek aroma, rasa, dan tekstur. Kemudian, lembar uji kualitas yang telah diisi oleh panelis akan dianalisis sehingga memperoleh kesimpulan.

bahan yang digunakan untuk membuat kue satu kara kratok.

a. Tepung Kara Kratok

Tepung kara kratok merupakan hasil olahan dari kara kratok kering yang melalui beberapa tahapan, diantaranya yaitu penyortiran, perendaman, pengupasan kulit ari, perebusan, pengeringan, penggilingan, dan pengayakan (Erni Widia Astuti, 2018). Dalam pembuatan kue satu, proses pembuatan tepung kara kratok, berbeda dengan proses penepungan kacang hijau sebab kara kratok memiliki $\mathrm{HCN}$ yang dapat dikurangi melalui proses perendaman dan perebusan sebelum ke tahap penggilingan.

b. Gula Halus

Gula halus adalah bahan masakan berbahan gula berbentuk tepung (Kusumawati, 2017). Gula halus terbuat dari tanaman tebu. Umumnya, gula berbentuk kristal, namun gula halus dibuat dalam bentuk kristal yang lebih kecil. Gula halus berwarna putih bersih dan memiliki rasa manis seperti gula biasa. Gula halus mengandung senyawa sukrosa atau senyawa gula yang mampu memberikan rasa manis pada makanan. Tujuan penggunaan gula halus dalam pembuatan kue satu ini adalah selain memberikan rasa manis, gula halus berfungsi untuk menyatukan bahan-bahan dalam adonan kue satu.

c. Vanili

Vanili adalah salah satu rempah yang sangat populer dalam pengolahan berbagai macam makanan dan minuman. Rempah ini memiliki aroma yang harum, khas, dan kuat. Bubuknya berwarna putih atau putih kecokelatan dengan tekstur 
yang agak kasar. Terkadang dijual juga dalam bentuk ekstrak cair (Sholihah S, 2015).

d. Garam

Garam adalah suatu zat berbentuk padat, kristal, dan berwarna putih yang merupakan hasil dari laut (Kusumawati, 2017). Garam diperoleh dari hasil pengeringan air laut sehingga didapatkan dari air laut yang asin. Garam membantu menambah cita rasa asin pada kue satu, namun dengan jumlah yang sedikit.

e. Air Hangat

Air merupakan bahan yang sangat penting bagi kehidupan manusia. Air memiliki rumus kimia $\mathrm{H} 2 \mathrm{O}$ yaitu satu molekul air tersusun atas du atom hidrogen dan satu atom oksigen. Air menjadi unsur utama yang terdapat dalam bahan pangan.

Air yang digunakan pada pembuatan kue satu kara kratok dengan syarat bersih dan jernih, tidak keruh, dan tidak berbau. Namun, air yang digunakan dengan suhu lebih tinggi atau sering disebut dengan air hangat suam-suam kuku dengan suhu $38^{\circ} \mathrm{C}-40^{\circ} \mathrm{C}$. Hal ini bertujuan agar dapat melembabkan adonan kue satu sehingga adonan dapat dipadatkan sebelum melalui proses pengeringan.

Selain bahan-bahan, peralatanperalatan dipersiapkan terlebih dahulu. Alat-alat yang digunakan diantaranya yaitu loyang, timbangan, waskom, saucier, bowl ukuran sedang, sendok teh, kompor, teplon, wajan, spatula, ballon wisk, saringan/pengayak tepung, gelas ukur, cetakan, dan serbet. Peralatan-peralatan yang digunakan dalam penelitian pembuatan kue satu kara kratok ini harus dipastikan alat-alat dalam keadaan bersih dan terbebas dari kotoran ataupun debu. Peralatan yang digunakan harus dicuci terlebih dahulu kemudian di keringkan dengan lap yang bersih dan bisa menyerap air.

\section{Tahap Pengolahan}

Berikut merupakan langkahlangkah dalam proses pembuatan kue satu kara kratok adalah sebagai berikut:

1) Mengayak Bahan

Bahan-bahan yang telah disiapkan yaitu tepung dan gula halus diayak terlebih dahulu agar memperoleh butiran-butiran halus dan terbebas dari partikel-partikel lainnya.

2) Mencampur Bahan

Bahan-bahan yang dicampurkan menjadi satu adalah tepung kara kratok, gula halus, dan garam menggunakan ballon wisk agar bahan-bahan tercampur rata. Kemudian, perciki dengan air hangat dan uleni hingga adonan lembab.

3) Pencetakan

Adonan kue satu yang sudah lembab, cetak satu per satu menggunakan cetakan.

4) Pengeringan

Tata kue satu yang telah dicetak di atas loyang. Kemudian keringkan. Dalam proses pengeringan dalam penelitian ini menggunakan teknik pengeringan alami yaitu menggunakan sinar matahari langsung selama 4 jam hingga adonan kue satu kering.

5) Pendinginan

Setelah adonan kue satu dijemur di bawah sinar matahari dan sudah kering, kemudian didinginkan terlebih dahulu agar suhu kue satu kembali ke suhu normal.

Tahap Pengemasan

Setelah proses pendinginan, kemudian kue satu dikemas menggunakan stoples.

\section{Hasil}

Berikut ini merupakan hasil tabulasi uji kualitas kue satu kara kratok, dibawah ini disajikan perhitungan uji kualitas kue satu kara kratok dilihat dari segi aroma, rasa, dan tekstur.

(a) Kualitas kue satu kara kratok dari aspek aroma

$$
\begin{aligned}
& M=\frac{\Sigma \mathrm{x}}{N} \\
& M=\frac{60}{20} \\
& M=3,00
\end{aligned}
$$

(b) Kualitas kue satu kara kratok dari aspek rasa 
Jurnal Bosaparis: Pendidikan Kesejahteraan Keluarga

Volume 10, Nomor 2, Juli 2019

$$
\begin{aligned}
& M=\frac{\Sigma x}{N} \\
& M=\frac{57}{20} \\
& M=2,85
\end{aligned}
$$

(c) Kualitas kue satu kara kratok dari aspek tekstur

$$
\begin{aligned}
& M=\frac{\Sigma \mathrm{x}}{N} \\
& M=\frac{57}{20} \\
& M=2,85
\end{aligned}
$$

Berdasarkan rumus pedoman konversi skala 3, maka hasil uji kualitas kue satu kara kratok dapat dilihat pada

\section{Tabel 1}

Hasil Uji Kualitas Kue Satu Berbahan Tepung Kara Kratok (Phaseolus lunatus L)

\begin{tabular}{lcc}
\hline Aspek yang Dinilai & Hasil & Kategori \\
\hline Aroma & 3,00 & Baik \\
Rasa & 2,85 & Baik \\
Tekstur & 2,85 & Baik \\
\hline
\end{tabular}

Berdasarkan hasil uji kualitas kue satu berbahan tepung kara kratok. a) kualitas kue satu kara kratok dari aspek aroma berada pada kategori baik sesuai dengan tolok ukur yaitu khas kacang kara kratok yang disebabkan oleh aroma kacang kara kratok sangat kuat. b) kualitas kue satu kara kratok dari aspek rasa berada pada kategori baik sesuai dengan tolok ukur yaitu manis yang disebabkan karena penambahan gula halus pada pembuatan kue satu. c) kualitas kue satu kara kratok dari aspek tekstur berada pada kategori baik sesuai dengan tolok ukur yaitu rapuh yang disebabkan karena proses pencetakan adonan kue satu. dapat dilihat pada Gambar 1 sebagai berikut.

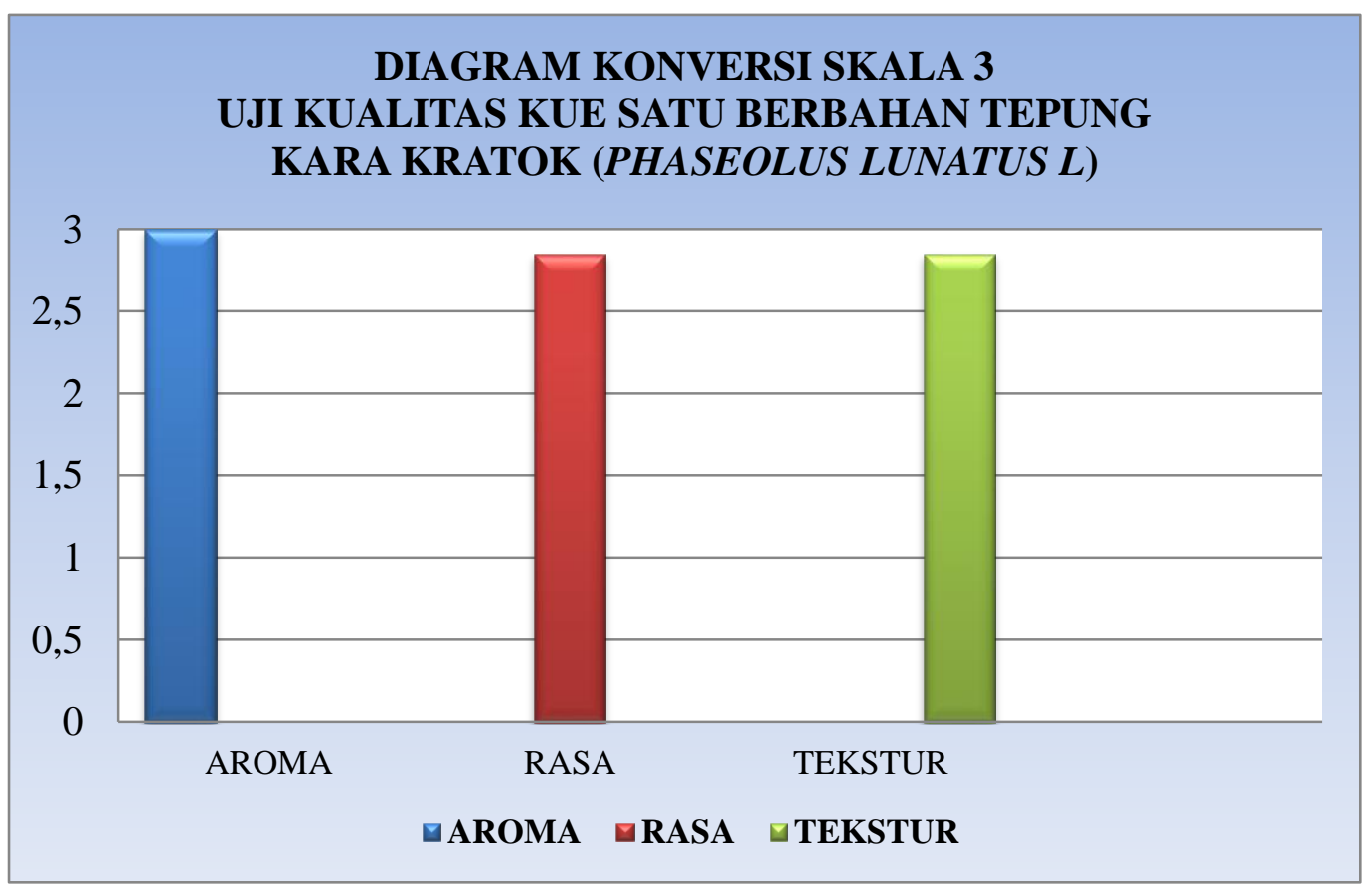

Gambar 1

Diagram Batang Kualitas Kue Satu Berbahan Tepung Kara Kratok (Phaseolus Iunatus $L$ 


\section{PEMBAHASAN}

Tepung merupakan partikel padat berbentuk butiran halus atau sangat halus tergantung pada proses penggilingannya. Proses pembuatan tepung kara kratok berbeda dengan proses pembuatan tepung kacang hijau yang digunakan sebagai bahan utama kue satu. Pembuatan tepung kara kratok melalui tahapan yang lebih banyak dibandingkan dengan pembuatan tepung kacang hijau.

Proses pembuatan tepung kacang hijau meliputi pengupasan kulit ari, penggilingan, dan pengayakan. Pada proses pembuatan kue satu kacang hijau, tepung kacang hijau yang sudah diayak disangrai terlebih dahulu untuk proses pematangan tepung kacang hijau. Kemudian, dicampur dengan bahanbahan tambahan lainnya diantaranya gula halus, vanili, garam, dan air hangat.

Proses pembuatan tepung kara kratok meliputi penyortiran, perendaman, pengupasan kulit ari, perebusan, pengeringan, penggilingan, dan pengayakan. Proses penepungan yang lebih banyak ini memiliki tujuan untuk mengurangi kandungan $\mathrm{HCN}$ yang terdapat di dalam kara kratok kering. Terutama pada proses perendaman dan perebusan. Karena pada tahap ini, $\mathrm{HCN}$ akan menguap dan berkurang. Pada proses pembuatan kue satu kara kratok, tepung kara kratok disangrai terlebih dahulu. Kemudian dicampur dengan bahan-bahan tambahan lainnya diantaranya gula halus, garam, dan air hangat. Pada kue satu kara kratok, tidak menggunakan bahan tambahan vanili dengan tujuan agar aroma khas kara kratok tetap terjaga.

Berdasarkan hasil uji panelis yang dilakukan, ditinjau dari aspek aroma diketahui bahwa kue satu berbahan tepung kara kratok (Phaseolus lunatus $L$ ) dengan skor 3,00 yang termasuk ke dalam kategori baik, sesuai dengan tolok

\section{SIMPULAN}

ukur yaitu beraroma khas kacang kara kratok. Semua panelis menyatakan bahwa aroma khas kara kratok yang sangat kuat sehingga kue satu berbahan tepung kara kratok memiliki aroma khas kacang kara kratok.

Berdasarkan hasil uji panelis yang dilakukan, ditinjau dari aspek rasa diketahui bahwa kue satu berbahan tepung kara kratok (Phaseolus lunatus $L$ ) dengan skor 2,85 yang termasuk ke dalam kategori baik yaitu rasa manis. Beberapa panelis menyatakan bahwa penambahan gula halus pada pembuatan kue satu kara kratok memberikan pengaruh terhadap rasa kue satu.

Berdasarkan hasil uji panelis yang dilakukan, ditinjau dari aspek tekstur diketahui bahwa kue satu berbahan tepung kara kratok (Phaseolus lunatus $L$ ) dengan skor 2,85 yang termasuk ke dalam kategori baik yaitu rapuh. Tekstur pada kue satu dipengaruhi oleh proses pencetakan adonan sebelum dijemur dan juga gula halus yang terpapar sinar matahari langsung akan mengikat adonan agar tetap menyatu.

Untuk memperoleh tekstur kue satu yang rapuh, tekanan pada saat mencetak adonan kue satu perlu diperhatikan. Apabila tekanan terlalu keras, kepadatan kue satu akan semakin keras, maka kue satu akan menjadi keras setelah dijemur. Apabila tekanan pada saat mencetak adonan tidak terlalu keras, maka akan memperoleh tekstur kue satu yang rapuh. Selain itu juga, suhu panas matahari juga dapat mempengaruhi tekstur kue satu. Apabila kue satu dijemur di bawah sinar matahari langsung dengan suhu yang besar dan waktu yang lama, tekstur kue satu akan menjadi keras yang disebabkan karena gula halus yang terpapar suhu panas dengan waktu yang lama, akan mengikat adonan kue satu sehingga teksturnya akan menjadi keras.

Kualitas kue satu berbahan tepung kara kratok (Phaseolus lunatus $L$ ) yang 
ditinjau dari aspek aroma, rasa, dan tekstur, masuk ke dalam kategori baik. Dari ketiga aspek tersebut, terdapat 2 aspek yang memiliki skor yang sama yaitu aspek rasa dan tektur. Dari segi aroma memiliki skor 3,00 masuk dalam kategori baik sesuai dengan tolok ukur yaitu khas kacang kara kratok. Hal ini disebabkan karena aroma kara kratok yang kuat. Dari aspek rasa memiliki skor 2,85 masuk dalam kategori baik sesuai dengan tolok

\section{SARAN}

Beberapa saran yang dapat disampaikan berdasarkan penelitian yang telah dilakukan adalah sebagai berikut.

Tepung kara kratok memiliki aroma yang khas. Bagi konsumen yang kurang menyukai aroma khas tepung kara kratok pada kue satu kara kratok, penambahan bahan vanili dapat menetralkan aroma kara kratok.

Kara kratok kering memiliki kandungan $\mathrm{HCN}$ yang tinggi, sehingga perlu diperhatikan proses pengolahannya. Tahap perendaman pada proses membuat tepung kara kratok perlu

\section{DAFTAR RUJUKAN}

Arikunto, Suharsimi. 2006. Prosedur Penelitian Suatu Pendekatan Praktik.

Jakarta : PT Rineka Cipta

Astuti, Ni Putu Erni Widia. 2018. "Uji Kualitas Tepung Kara Kratok". Universitas

Pendidikan Ganesha Vol. 8, No.2 tersedia dalam

http://ejournal.undiksha.ac.id (diakses pada 2 Desember 2018)

Budianto A K. 2009. Pangan, Gizi, dan Pembangunan Manusia Indonesia : Dasar-dasar IImu Gizi. Malang: UMM Press

Damiati. 2011. Patiseri Nusantara. Buku Ajar. Singaraja : Universitas Pendidikan Ganesha (tidak diterbitkan) ukur yaitu manis. Hal ini disebabkan karena penambahan gula halus pada pembuatan kue satu. Dari aspek tekstur memiliki skor 2,85 masuk dalam kategori baik sesuai dengan tolok ukur yaitu rapuh. Tekstur kue satu dipengaruhi oleh pada saat proses pencetakan adonan kue satu dan gula halus yang berfungsi mengikat adonan agar tetap menyatu karena terkena paparan sinar matahari.

diperhatikan sebagai upaya mengurangi kandungan HCN pada tepung kara kratok.

Sebagai upaya mengoptimalkan pemanfaatan tepung kara kratok, tepung kara kratok dapat dijadikan sebuah produk kue kering yaitu kue satu sehingga dapat menambah nilai ekonomis kara kratok kering.

Berdasarkan syarat tumbuh kara kratok yang mudah, dan kandungan protein tepung kara kratok yang tinggi, untuk peneliti selanjutnya disarankan untuk menambah keanekaragaman produk dari tepung kara kratok agar dapat meningkatkan nilai ekonomis dari tepung kara kratok.

Diniyah, N. dkk. 2015. "Sifat Fungsional Tepung Koro Kratok Hitam, Merah, dan Putih (Phaseolus lunatus $L$ ) dengan Prilaku Lama Perendaman". Jurnal Hasil Penelitian Industri, Vol. 28, No. 2

Fachni. 2016. "Kue Satu Jawa Barat". Tersedia pada : https://budayaindonesia.org/Kue-Satu-1/ (diakses tanggal 18 April 2019)

https://id.wikipedia.org/wiki/Kacang_kratok (diakses tanggal 2 Desember 2018)

http://kacangkratok.kahuripan.web.id/id1/28592746/KacangKratok_97456_kacang-kratokkahuripan.html (diakses tanggal 2 
Jurnal Bosaparis: Pendidikan Kesejahteraan Keluarga

Volume 10, Nomor 2, Juli 2019

Desember 2018)

https://id.wikipedia.org/wiki/Tepung diakses pada tanggal 19 April 2019

https://id.m.wikipedia.org/wiki/Kue diakses pada tanggal 19 April 2019

Khotimah, Kusnul. 2014. "Uji Kualitas Kue Kering (Kue Satu) Kacang Koro Pedang (Canavalia Ensiformis (L) $D C)$ dengan Teknik Pengolahan Dijemur dan Dioven)". Skripsi (tidak diterbitkan). Jurusan Pendidikan Kesejahteraan Keluarga. Universitas Pendidikan Ganesha. Singaraja

Koyan, 2011. Asesmen Dalam Pendidikan. Singaraja: Universitas Pendidikan Ganesha

Kusumawati, Meilisa. 2017. "Gula Halus". Tersedia pada http://www.kerjanya.net/s/Gula+hal us (diakses pada tanggal 18 Agustus 2019)

Kusumawati, Meilisa. 2017. "Garam". Tersedia pada http://www.kerjanya.net/Garam (diakses pada tanggal 18 Agustus 2019)

Sanjaya, Y., dan Wiwin, S. 2005. "Keragaman Serangga pada Tanaman Roay (Phaseolus lunatus)". Vol. 6, No. 4 Oktober 2005

Sholihah S, Niasaa. 2015. "Vanili". Tersedia pada http://www.kerjanya.net/fac/18062vanili.html (diakses pada tanggal 18 Agustus 2019)

Sri, Handajani., Dian. R., Pramita. D.S. 2008. Karakteristik Kimia (HCN, Antioksidan dan Asam Fitat) Beberapa Jenis Koro Lokal Dengan Berbagai Perlakuan Pendahuluan. Makalah disampaikan pada Widyakarya Nasional Pangan dan Gizi. Jakarta
Subagio, A., W.S. Windrati, and Y. Witomo. 2003. Development of Functional.

Proteins From Some Local NonOilseed Legumes As Food Additives Paper Presented on Indonesian Toray Sciene Foundation (ITSF). Seminar. (Tidak diterbitkan).

Susanto, T. Dan B. Saneto. 1994. Teknologi Pengolahan Hasil Pertanian. Surabaya - Bina IImu

UPT. Laboratorium Analitik Universitas Udayana, 2019

Utomo, JS dan SS Antarlina. 1998. "Teknologi Pengolahan dan Produk-produk Kacang Tunggak". Monograf Balitkabi, No. 3 